\title{
Exogenous tannase improves feeding value of a diet containing field beans (Vicia faba) when fed to broilers
}

by Abdulla, J., Rose, S.P., Mackenzie, A.M., Mirza, W. and Pirgozliev, V.

Copyright, Publisher and Additional Information: This is the author accepted manuscript. The final published version (version of record) is available online via Taylor \& Francis Please refer to any applicable terms of use of the publisher.

DOI: $10.1080 / 00071668.2016 .1143551$

Harper Adams

University 
1 Exogenous tannase improves feeding value of diet containing field beans (Vicia faba) when fed to broilers

3

4 J. Abdulla, S.P. Rose, A.M. Mackenzie, W. Mirza, V. Pirgozliev*

5 The National Institute of Poultry Husbandry, Harper Adams University, Shropshire, TF10 $6 \quad 8 \mathrm{NB}, \mathrm{UK}$

7

8 Correspondence to: vpirgozliev@ harper-adams.ac.uk

10 Abstract 1. A total of 72 male Ross 308 broilers were used in a study to investigate the effect 11 of dietary tannase on apparent metabolisable energy (AME), coefficients of dry matter 12 (DMR) and nitrogen (NR) retention and fat digestibility (FD) of a diet containing 300g/kg 13 field beans (Vicia faba). Growth performance variables and gastrointestinal tract 14 development were also measured.

15 2. Two treatments were used in this study: control (C) and $C+3400$ tannase units (TU) per $16 \mathrm{~kg}$ feed. Diets were formulated to be nutritionally adequate with the exception that the AME 17 was lower than recommended (12.65 MJ/kg vs $12.97 \mathrm{MJ} / \mathrm{kg}$, respectively).

18 3. Inclusion of tannase increased AME by $0.4 \mathrm{MJ} / \mathrm{kg} \mathrm{DM}(\mathrm{P}<0.05)$. Tannase supplementation 19 improved dietary DMR $(\mathrm{P}<0.05)$, NR $(<0.001)$ and $\mathrm{FD}(\mathrm{P}<0.05)$ by $2.8,3.2$ and $6.5 \%$, 20 respectively.

21 4. Birds fed tannase had $4.4 \%$ reduction in feed intake and $2.6 \%$ improvement in gain to feed ratio $(\mathrm{P}<0.05)$. Compared to control diet, birds fed tannase had reduced relative to body

23 weight $(\% \mathrm{BW})$ proventriculus and gizzard and pancreas weights, 3.29 vs $3.09 \%$ and $0.47 \mathrm{vs}$ $240.44 \%$, respectively.

25 5. The mechanisms of action of the studied enzyme require further elucidation. 
26 Global demand for dietary protein has recently led to an unstable increase in the supply and

27 price of soybean. In addition, the use of soybeans has led to consumer resistance because much of it comes from genetically modified crops unsuitable for use in organic farming (Vicenti et al., 2009). These circumstances have stimulated research on alternative protein sources, especially high-protein legumes, free of genetic modifications that can satisfy the protein requirements (Ravindran et al., 2010; Laudadio et al., 2011). The content of antinutrients in field beans (Vicia faba), primarily polysaccharides and tannins, are the main reason reduced nutrient digestibility and growth performance of broilers fed field bean based diets (Longstaff and McNab, 1991). Although the beneficial effect of feeding fibre degrading enzymes to legume containing diets is known (Castanon and Marquardt, 1989; Cowieson et al., 2004) there is lack of information on the effect of tannin degrading enzymes on feeding value of field beans for broilers.

The main objective of this experiment, therefore, was to determine the effect of supplementary tannase, an enzyme that hydrolyses tannins, on dietary metabolisable energy, nutrient utilisation and gastrointestinal tract development. The overall feed intake, weight gain and feed conversion efficiency of the birds were also measured.

\section{MATERIALS AND METHODS}

\section{Materials and methods}

Field bean sample

A UK grown field bean sample of cultivar Sultan from 2013 harvest year was used in a broiler feeding experiment. This field bean cultivar was selected for the experiment because of its relatively high content of hydrolysable tannins and low metabolisable energy (Abdulla et al., 2015). Before the animal feeding experiment, the sample was hammer-milled using a 4 
mm screen and then mixed in a horizontal mixer with the other feed ingredients. Freshly milled sample in duplicate was used for analyses and in the feeding study to avoid spoilage.

52 The gross energy (GE) of the bean samples was determined using a bomb calorimeter (Parr Instrument Company, Moline, IL). Nitrogen was determined by the combustion method (AOAC, 2000) using a LECO (FP-528 N, LECO Corp., St. Joseph, MI). The crude protein (CP) values were obtained as $\mathrm{N} x$ 6.25. Oil (as ether extract) in the bean sample was extracted with diethyl ether by the ether extraction method (AOAC, 2000) using a Soxtec system (Foss UK Ltd.). The contents of non-starch polysaccharides (NSP), hydrolysable tannins (HT) and trypsin inhibitors (TI) in the experimental field bean sample were determined by the methods of Englyst et al. (1994), Makkar et al. (1993) and Smith et al. (1980), respectively.

\section{Diet preparation}

61 A control diet (C) containing $300 \mathrm{~g} / \mathrm{kg}$ field bean sample was prepared (Table 1). The diet

62 was then split into two batches and one of them was supplemented with 3400 units/kg (TU)

63 of propriety tannase (Kerry Ingredients and Flavours, Osberstown, Naas, Co. Kildare, 64 Ireland) resulting in diet CT. The enzyme had also 6220 units/kg of pectinase and less than 65200 units/kg of phytase activity. The enzyme preparation was based on tannase produced by 66 Aspergillus niger. The enzyme was in a liquid form and $17 \mathrm{ml} / \mathrm{kg}$ was sprayed on the top of 67 diet CT. The dry matter content of diet C was adjusted by spraying of $17 \mathrm{ml}$ water per $\mathrm{kg}$ of diet. After spraying the diets were thoroughly mixed in a horizontal mixer.

69 Birds, husbandry and sample collection

70 All procedures were approved by The Animal Experimental Committee of Harper Adams 71 University. 
Male Ross 308 broiler chickens were obtained from a commercial hatchery at one-day old and were placed in a single floor pen and fed on a proprietary broiler starter feed until $6 \mathrm{~d}$ of age. On the first day of the experimental period (at $7 \mathrm{~d}$ of age), the chicks were individually weighed and assigned to one of the experimental pens. Two birds were placed in each pen (0.4m X $0.4 \mathrm{~m}$ solid floor area) within a controlled environment room. Each diet was fed at random to 16 pens from 7 to $21 \mathrm{~d}$ age. Room temperature and lighting program followed commercial recommendations (Aviagen Ltd., Edinburgh, UK). Access to the mash form feed and the water was ad libitum.

During the last four days of the experiment, from 17 to $21 \mathrm{~d}$ age, the solid floor of each pen was replaced with a wire mesh. All excreta were collected daily and refrigerated. On the last collection the samples from each pen were pooled, the total amount was immediately dried at $60{ }^{\circ} \mathrm{C}$ and then milled. Representative samples of dry and milled excreta were taken for analyses. Feed intakes were also measured for the same period.

On the last day of the study, at 21d age, the two birds in each pen were weighed and killed by cervical dislocation. The empty weights of gastrointestinal tract (GIT) segments, including proventriculus and gizzard (PG), pancreas and small intestine, of each bird were determined, according to the procedures described by Amerah and Ravindran (2008). The weights of the segments were presented as relative to $\mathrm{BW}(\% \mathrm{BW})$.

\section{$\underline{\text { Metabolisable energy and nutrient utilisation determination }}$}

Excreta were oven-dried in forced draft oven at $60^{\circ} \mathrm{C}$ to constant weight, weighed, and milled to pass through a $0.75 \mathrm{~mm}$ mesh. The gross energy, nitrogen and oil in feed and excreta were determined as for the field bean sample. The dietary $\mathrm{N}$-corrected apparent metabolisable energy (AMEn) was calculated as described by Hill and Anderson (1958). The coefficients of total tract fat dry matter (DMR) and nitrogen retention (NR), and fat digestibility (FD) were 
96 determined as the difference between the respective nutrient intake and nutrient excreted

97 divided by the intake.

\section{STATISTICAL ANALYSES}

99 Statistical analyses were performed using the Genstat statistical software package (Genstat

100 15th release 3.22 for Windows; IACR, Rothamstead, Hertfordshire, UK). The metabolisable energy content of the experimental diets, broiler growth performance, and nutrient utilisation were compared statistically by ANOVA. In all instances, differences were reported as

103 significant at $\mathrm{P}<0.05$.

\section{RESULTS AND DISCUSSION}

105 The determined chemical composition of the Sultan cultivar field bean sample contained $106856 \mathrm{~g} / \mathrm{kg}$ dry matter, $18.27 \mathrm{MJ} / \mathrm{kg}$ GE, $245 \mathrm{~g} / \mathrm{kg} \mathrm{CP}, 12 \mathrm{~g} / \mathrm{kg}$ oil, $190 \mathrm{~g} / \mathrm{kg}$ total NSP (135g 107 non-soluble and $55 \mathrm{~g}$ soluble), $12.3 \mathrm{mg} / \mathrm{g}$ HT and $2.3 \mathrm{mg} / \mathrm{g} \mathrm{TI}$, respectively (results are

108 presented on dry matter basis). All birds were healthy throughout the study period and there

109 was no mortality. There was no effect of treatment on final body weight and weight gain of

110 the birds (Table 2). Birds fed diet TC had reduced feed intake (FI) but improved feed 111 conversion efficiency $(\mathrm{FCE})(\mathrm{P}<0.05)$ compared to the control fed birds.

112 Exogenous tannase supplementation improved dietary AMEn by $0.4 \mathrm{MJ} / \mathrm{kg}$ compared to the

113 control $(\mathrm{P}<0.05)$ (Table 3). Similarly, tannase supplementation resulted in improved DMR, $114 \quad \mathrm{NR}$ and FD $(\mathrm{P}<0.05)$.

115 Birds fed tannase had reduced the relative proventriculus and gizzard weight, and also 116 reduced the relative pancreas weights compared to birds fed the control diet $(\mathrm{P}<0.05)($ Table

117 4). There was no effect $(\mathrm{P}>0.05)$ of dietary treatment on the relative weight of the small 118 intestine. 
119 The study evaluated the efficacy of supplementary tannase enzyme on growth performance, 120 energy and nutrient utilisation and GIT development when field bean diet was fed to broilers.

121 The data demonstrate that young broilers are sensitive to dietary supplementation with 122 exogenous tannase. There are no previous published studies of dietary tannase 123 supplementation in broiler feeds. However, there are published reports on the negative impact 124 of high dietary tannin on the studied variables (Jansman, 1993; Brufau et al., 1998; O'Neill et 125 al., 2012).

126 The diets were relatively high in HT content from the Sultan field bean cultivar inclusion 127 (approximately $3.5 \mathrm{~g} / \mathrm{kg}$ diet). The growth of the birds did not differ between diets and was in 128 the expected range for broilers reared in similar environment and fed mash diets (Karadas et 129 al., 2014; Pirgozliev et al., 2015a, 2015b). In agreement with improved AMEn and nutrient 130 utilisation, birds fed tannase supplemented diet had an improved FCE. This is in line with 131 Kubena et al. (1983) who reported reduced feed efficiency when high tannin diets were fed to 132 poultry.

133 Tannins are able to form complexes with proteins, so they can also bind to enzymes, which 134 have implications for their biological activity. It has been reported that high-tannin inclusion reduces the activities of all digestive enzymes in various in vitro and in vivo assays (Griffiths, 1979; Griffiths \& Moseley, 1980; Singh, 1984). This supports the increased nutrient

137 utilisation coefficients in the recent report suggesting that exogenous tannase was able to 138 hydrolise at least part of the dietary tannins and alleviate their negative impact observed in 139 other studies. This is in line with the observed improved AME, N and amino acid digestibility 140 of broilers when fed diets low in tannin compared to high tannin diets (Nyachoti et al., 1996;

141 Brufau et al., 1998; O'Neill et al., 2012). 
142 Kubena et al. (1983) and Ahmed et al. (1991) also found an increased pancreas in broilers fed

143 high-tannin diets. Similar to trypsin inhibitors, tannins are also able to form complexes with

144 proteins and bind to enzymes, thus tannins may stimulate pancreatic secretion in a manner

145 analogous to that of proteinase inhibitors from legume seeds (Griffiths, 1980), suggesting an

146 explanation on the reduced pancreas size in birds fed tannase in this study.

147 Kubena et al. (1983) found that the weights of PG of birds fed high tannin feed (15 g tannic

148 acid per kg diet) was lower compared to the control fed birds. This is the opposite of our

149 findings that reducing dietary tannin (via supplementing diets with tannase) reduced the

150 relative $\mathrm{PG}$ weights of birds. In the present study the diets contained about $3.5 \mathrm{~g} / \mathrm{kg}$

151 hydrolysable tannins (measured as tannic acid), although Kubena et al. (1983) had $15 \mathrm{~g}$ tannic

152 acid per $\mathrm{kg}$ diet.

153 In conclusion supplementation of field bean-based diets with tannase enzyme improved feed

154 efficiency, dietary metabolisable energy and nutrient utilisation. Although the beneficial

155 effects associated with tannase treatment were in line with pancreatic size reduction, it is

156 possible that the pectinase activity in the tannase preparation may have also influenced the

157 responses of the birds. The mechanisms require further elucidation.

158 DISCLOSURE STATEMENT

159 No potential conflict of interest was reported by the authors.

160 ACKNOWLEDGEMENTS

161 Mr Jalil Abdulla is grateful for the financial support from the Kurdistan Regional

162 Government - Iraq. Special thanks to Mr Paddy Barrett (Askew \& Barrett (Pulses) Ltd) who 163 donated some of the field bean samples. 
Table 1. Diet formulation ( $\mathrm{g} / \mathrm{kg}$ 'as-fed') of the diets

167

\begin{tabular}{|l|c|}
\hline Ingredient & \\
\hline Wheat & 404.2 \\
\hline Soybean meal $(480 \mathrm{~g} / \mathrm{kg} \mathrm{CP})$ & 27.0 \\
\hline Full-fat soybean & 127.5 \\
\hline Maize gluten meal & 35.0 \\
\hline Field bean & 300.0 \\
\hline Soya oil & 65.0 \\
\hline Lysine HCl & 2.3 \\
\hline DL Methionine & 5.8 \\
\hline L Threonine & 2.4 \\
\hline Monocalcium phosphate & 10 \\
\hline Limestone & 14.0 \\
\hline Salt & 2.8 \\
\hline Vitamin-trace mineral premix* & 4.0 \\
\hline & 1000 \\
\hline Calculated nutrient composition & \\
\hline ME (MJ/kg) & 12.65 \\
\hline Protein (g/kg) & 212 \\
\hline Lysine (g/kg) & 12.4 \\
\hline Met + Cys (g/kg) & 9.4 \\
\hline Ca (g/kg) & 8.2 \\
\hline P non-phytate (g/kg) & 4.0 \\
\hline Determined nutrient composition & \\
\hline Gross energy (MJ/kg DM) & 18.34 \\
\hline Protein (g/kg) & 171 \\
\hline Fat (g/kg) & 132 \\
\hline Dry matter (g/kg) & 885 \\
\hline & \\
\hline
\end{tabular}

* Vitamin and trace-mineral premix provided per kg diet: $\mu \mathrm{g}$ : retinol 2160 , cholecalciferol 75; mg: alpha-tocopherol 25, menadione 1.5, riboflavin 5, pantotenic acid 8, cyanocobalamin 0.01 , pyridoxine 1.5 , thiamine 1.5 , folic acid 0.5 , niacin 30 , biotin $0.06, \mathrm{I} 0.8, \mathrm{Cu} 10, \mathrm{Fe} 80$, Se 0.3, Mn 80, Zn 80. Diets were not supplemented with coccidiostat 
186

187

188

189

190

191

192

193

194

\begin{tabular}{|l|c|c|c|c|}
\hline & Total GIT $(\%$ BW) & P\&G (\% BW) & SI (\% BW) & Pancreas (\% BW) \\
\hline Control & 9.39 & 3.29 & 5.64 & 0.47 \\
\hline Tannase & 9.26 & 3.09 & 5.73 & 0.44 \\
\hline SEM $(\mathrm{df=}=31)$ & 0.102 & 0.048 & 0.104 & 0.008 \\
\hline P & 0.363 & 0.012 & 0.565 & 0.042 \\
\hline
\end{tabular}

203 Each mean represents values from 16 replicate pens; Gastrointestinal tract development were 204 determined at $21 \mathrm{~d}$ old using the bigger birds in each pen; There is statistically significant 205 difference between treatments when $\mathrm{P} \leq 0.05$. GIT - gastrointestinal tract; $\mathrm{P} \& \mathrm{G}-$ 206 proventriculus and gizzard; SI - small intestine. 
209 Abdulla, J., Pirgozliev, V., Rose, S.P. and Mackenzie, A.M. (2015) Feeding quality of field

210 beans for broiler chickens, WPSA meeting Chester 13-15 April. British Poultry Abstracts- in 211 press

213 Ahmed, A. E., Smithard, R., and Ellis, M. (1991) Activities of enzymes of the pancreas, and 214 the lumen and mucosa of the small intestine in growing broiler cockerels fed on tannin215 containing diets. British Journal of Nutrition, 65: 189-197.

217 Amerah, A.M. and Ravindran, V. (2008) Influence of method of whole-wheat feeding on the 218 performance, digestive tract development and carcass traits of broiler chickens. Animal Feed 219 Science and Technology, 147: 326-339.

220

221 Association of Official Analytical Chemists. 2000. Official Methods of Analysis. 17th ed. 222 AOAC, Gaithersburg, MD.

224 Brufau, J., Boros, D. and Marquardt, R.R. (1998) Influence of growing season, tannin content 225 and autoclave treatment on the nutritive value of near-isogenic lines of faba beans (Vicia faba L.) when fed to leghorn chicks. British poultry science, 39: 97-105. 
228 Castanon, J.L., and R.R. Marquardt, (1989) Effect of enzyme addition, autoclaved treatment and fermenting on the nutritive value of field beans (V. faba L.). Animal Feed Science and

230 Technology, 26: 71-79.

231

232 Cowieson, A.J., Acamovic, T. and Bedford, M.R. (2003) Supplementation of diets containing 233 pea meal with exogenous enzymes: effects on weight gain, feed conversion, nutrient 234 digestibility and gross morphology of the gastrointestinal tract of growing broiler chicks. 235 British poultry science, 44: 427-437.

237 Englyst, H.N., Quigley, M.E. and Hudson, G. J. (1994) Determination of dietary fibre as non238 starch polysaccharides with gas-liquid chromatographic, high-performance liquid 239 chromatographic or spectrophotometric measurement of constituent sugars. Analyst, 119: $240 \quad 1497-1509$.

242 Griffiths, D.W. (1979) The inhibition of digestive enzymes by extracts of field bean (Vicia

243 faba). Journal of the Science of Food and Agriculture, 30: 458-462.

245 Griffiths, D. W. (1980). The inhibition of digestive enzymes by polyphenolic compounds, In:

246 Friedman, M. (ED) Nutritional and Toxicological Significance of Enzyme Inhibitors in Food, 247 pp. 509-516 (New York, Plenum Press). 
249 Griffiths. D.W. and Moseley, G. (1980) The effect of diets containing field beans of high or 250 low polyphenolic content on the activity of digestive enzymes in the intestines of rats.

251 Journal of the Science of Food and Agriculture, 31: 255-259.

253 Hill, F. W. and Anderson, D. L. (1958) Comparison of metabolisable energy and productive energy determinations with growing chicks. Journal of Nutrition, 64: 587-603.

255

256 Jansman, A.J.M. (1993) Tannins in feedstuffs for simple stomached animals. Nutrition 257 Research Reviews, 6: 209-236.

258

259 Karadas, F. Pirgozliev, V. Rose, S.P. Dimitrov, D. Oduguwa, O. and Bravo, D. (2014) 260 Dietary essential oils improve the hepatic anti-oxidative status of broiler chickens. British 261 Poultry Science, 55: 329-334.

263 Kubena, L. F., Phillips, T. D., Creger, C. R., Witzel, D. A. and Heidelbaugh, N. D. (1983)

264 Toxicity of ochratoxin A and tannic acid to growing chicks. Poultry science, 62: 1786-1792. 265

266 Laudadio, V., Ceci, E. and Tufarelli, V. ( 2011) Productive traits and meat fatty acid profile 267 of broiler chickens fed diets containing micronized fava beans (Vicia faba L. var. minor) as 268 the main protein source. The Journal of Applied Poultry Research, 20: 12-20. 
Longstaff, M. and McNab, J.M. (1991) The inhibitory effects of hull polysaccharides and

271

272

273

274

275

276

277

278

279

280

281

282

283

284

285

286

287

288

289

290

291 tannins of field beans (Vicia faba L.) on the digestion of amino acids, starch and lipid and on digestive enzyme activities in young chicks. British Journal of Nutrition, 65: 199-216.

Makkar, H.P., Blümmel, M., Borowy, N.K. and Becker, K. (1993) Gravimetric determination of tannins and their correlations with chemical and protein precipitation methods. Journal of the Science of Food and Agriculture, 61: 161-165.

Nyachoti, C. M., Atkinson, J. L. and Leeson, S. (1996) Response of broiler chicks fed a hightannin sorghum diet. The Journal of Applied Poultry Research, 5: 239-245.

O’Neill, H.M., Rademacher, M., Mueller-Harvey, I., Stringano, E., Kightley, S. and Wiseman, J. (2012) Standardised ileal digestibility of crude protein and amino acids of UKgrown peas and faba beans by broilers. Animal Feed Science and Technology, 175: 158-167.

Pirgozliev, V., Karadas, F., Rose, S.P., Beccaccia, A. Mirza, M.W. and Amerah, A.M. (2015a) Dietary xylanase increases hepatic vitamin E concentration of chickens fed wheat based diet. Journal of Animals and Feed Sciences, 24: 80-84.

Pirgozliev, V., Whiting, I., Wilson, J., Rose, S.P., Mirza, M.W., Ivanova S. and Kanev, D. (2015b) Nutrient availability of wheat distillers dried grains with solubles (DDGS) for broilers. Zivotnovudni Nauki, 4: 17-24. 
293 Ravindran, G., Nalle, C. L., Molan, A. and Ravindran, V. (2010) Nutritional and biochemical

294 assessment of field peas (Pisum sativum L.) as a protein source in poultry diets. The Journal 295 of Poultry Science, 47: 48-52.

297 Singh, U. (1984). The inhibition of digestive enzymes by polyphenols of chickpea (Cicer 298 urierinum L.) and pigeonpea (Cajanus rajan (L.) Millsp.). Nutrition Reports Inrernational29. $29974 S 753$.

300

301 Smith, C., Van Megen, W., Twaalfhoven, L. and Hitchcock, C. (1980) The determination of 302 trypsin inhibitor levels in foodstuffs. Journal of the Science of Food and Agriculture, 31: $303 \quad 341-350$.

304

305 Vicenti, A., Toteda, F., Turi, L.D., Cocca, C., Perrucci, M., Melodia, L. and Ragni, M. (2009)

306 Use of sweet lupin (Lupinus albus L. var. Multitalia) in feeding for Podolian young bulls and

307 influence on productive performances and meat quality traits. Meat science, 82: 247-251. 